First Peoples Child \& Family Review

A Journal on Innovation and Best Practices in Aboriginal Child Welfare Administration,

\title{
Qallunaat Crossing: The Southern-Northern Divide and Promising Practices for Canada's Inuit Young People
}

\section{Shannon Moore, Wende Tulk and Richard Mitchell}

Volume 2, Number 1, 2005

URI: https://id.erudit.org/iderudit/1069541ar

DOI: https://doi.org/10.7202/1069541ar

\section{See table of contents}

\section{Publisher(s)}

First Nations Child and Family Caring Society of Canada

\section{ISSN}

1708-489X (print)

2293-6610 (digital)

Explore this journal

\section{Cite this article}

Moore, S., Tulk, W. \& Mitchell, R. (2005). Qallunaat Crossing: The Southern-Northern Divide and Promising Practices for Canada's Inuit Young People. First Peoples Child \& Family Review, 2(1), 117-129.

https://doi.org/10.7202/1069541ar

\section{Article abstract}

Life for Inuit communities in Canada's northern territory of Nunavut has been impacted by rapid change over the past fifty years in particular, a pattern that has similarly impacted First Peoples' communities across the southern portion of the country for centuries. Unfortunately, inadequate resources often leave young people from Nunavut challenged to safely navigate these abrupt changes within their communities and culture. The chronic lack of resources for young people is compounded by the lack of educational opportunities for Inuit adults to enter professional roles in support of the region's next generation. As a result, non-Inuit (or Qallunaat) professionals from southern Canada are frequently recruited. This paper examines some of the challenges faced by Inuit communities and Qallunaat professionals as they traverse the North/South divide within a cross-cultural educational context. This process is characterized by struggles and joy in finding the balance between meeting young people's basic social and emotional needs, and professionals who are often illprepared to teach and learn within a cultural context with which they have little familiarity. In response, the authors describe some of the unique attributes of Inuit life and some of the many challenges faced by young people. They also suggest that a " transdisciplinary" approach be established (Holmes and Gastaldo, 2004) towards educating Qallunaat professionals as an important step in achieving effective practice within northern communities- one which integrates knowledge from Inuit Elders with cross-cultural counseling techniques, multicultural competency development and practice-based wisdom. Specific application of these skills will be explored in this paper to illustrate ways of engaging "multiculturalism" within this context while accounting for the right of Canada's Inuit young people to have their basic social, emotional and cultural needs recognized during a transformative historical epoch.
This document is protected by copyright law. Use of the services of Érudit (including reproduction) is subject to its terms and conditions, which can be viewed online.

https://apropos.erudit.org/en/users/policy-on-use/ 


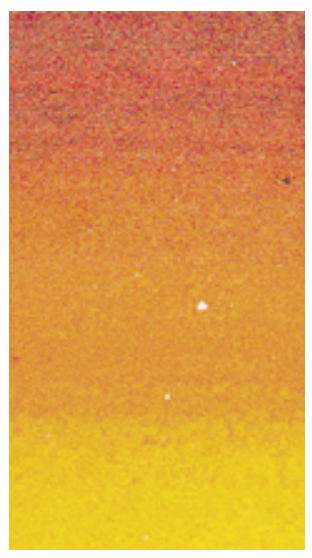

\title{
Qallunaat Crossing;
}

\author{
The Southern-Northern Divide and Promising Practices
}

for Canada's Inuit Young People *

\section{Shannon Moore, Wende Tulk and Richard Mitchell}

\section{Abstract}

Life for Inuit communities in Canada's northern territory of Nunavut has been impacted by rapid change over the past fifty years in particular, a pattern that has similarly impacted First Peoples' communities across the southern portion of the country for centuries. Unfortunately, inadequate resources often leave young people from Nunavut challenged to safely navigate these abrupt changes within their communities and culture. The chronic lack of resources for young people is compounded by the lack of educational opportunities for Inuit adults to enter professional roles in support of the region's next generation. As a result, non-Inuit (or Qallunaat) professionals from southern Canada are frequently recruited.

This paper examines some of the challenges faced by Inuit communities and Qallunaat professionals as they traverse the North/South divide within a crosscultural educational context. This process is characterized by struggles and joy in finding the balance between meeting young peoples' basic social and emotional needs, and professionals who are often ill-prepared to teach and learn within a cultural context with which they have little familiarity. In response, the authors describe some of the unique attributes of Inuit life and some of the many challenges faced by young people. They also suggest that a "transdisciplinary" approach be established (Holmes and Gastaldo, 2004) towards educating Qallunaat professionals as an important step in achieving effective practice within northern communities - one which integrates knowledge from Inuit Elders with cross-cultural counselling techniques, multicultural competency development and practice-based wisdom. Specific application of these skills will be explored in this paper to illustrate ways of engaging "multiculturalism" within this context while accounting for the right of Canada's Inuit young people to have their basic social, emotional and cultural needs recognized during a transformative historical epoch. 


\section{Introduction}

This paper is a response to the need for enhancing transdisciplinarity for non-Inuk (Qallunaat) professionals when working with the young people of Canada's most northern territory, Nunavut. While initiatives such as the Akitsiraq Law School and its recent graduating class of 11 new Inuit lawyers have focused on creation of educational opportunities for Inuk people within their home communities (see Mankin, 2005) such opportunities are rare in remote Arctic regions. As a result, Qallunnaat will continue to be recruited to practice in the North for the foreseeable future, and may even provide the type of "bridging frameworks" suggested by Dahlberg, Moss and Pence (1999, p. 164 ) as integral to the evolution of children's education. Holmes and Gastaldo (2004) suggest this trend towards "transdisciplinarity" is moving beyond traditional professional perspectives by allowing diversity and plurality to include alternative forms of knowledge that cross disciplinary boundaries (p. 259). As an example, transdisciplinary teaching professionals are now called upon to have both educational and social welfare roles in their day-to-day work with young people.

The authors of this paper argue that Qallunaat professionals could benefit from a similar transdisciplinary understanding of Inuit culture, the unique challenges faced by northern communities, and specifically, by Inuit young people themselves. Towards this end, the paper has been co-written by Shannon Moore, a clinical counsellor and graduate instructor within Brock University's Faculty of Education with an interest in cross-cultural counselling and restorative justice; Wende Tulk, an educator in Nunavut for the past decade and a recent graduate of Brock University's Faculty of Education; and Richard Mitchell, a child and youth rights researcher and instructor within Brock University's Child and Youth Studies Department.

The paper explores aspects of Northern life for transplanted professionals while suggesting strategies for integrating practical, cross-cultural competencies in the support of promising practice for (C) Moore, Tulk and Mitchell
Qallunaat and the benefit of Inuit young people. To achieve this aim, the paper is organized into several sections. To begin, an overview of challenges characterizing northern life is offered the current cultural/ historical context. Next, a critical reflection written by a Qallunaat teacher from her lived experience in the North is presented. Finally, strategies to address the challenges described throughout the paper are provided through a synthesis of insights from Inuit Elders and healers, cross-cultural counselling discourses, and practice-based wisdom.

\section{Overview of Current Challenges}

The challenge of survival has historically been integral to Inuit communities and this has been magnified by the dramatic rate of social, cultural and environmental change faced by these Aboriginal peoples (Kulchyski, Mc Caskill, \& Newhouse, 1999; Kusugak, 2004; Statistics Canada, 2001a; 2001b; Uyarasuk, 1999). This is expressed poignantly through the voice of an Inuit women's association:

Unparalleled rate of change: It would be difficult to overstate the effect on Inuit women of the fact of their culture changing in less than fifty years from an isolated, family-centred economy, based on subsistence hunting and seasonal relocation, through fractured family structures and children taken far away and educated in a foreign language and culture, to population migration from small communities to regional centres and an economy of wage earning employment and life in permanent housing (Dickson, 2004, p. 5).

This atmosphere of profound transformation has leveled a severe cost on the Indigenous people of the Canadian north.

As one result, from across disciplines the non-Inuk professionals who are recruited to practice in this Arctic region need to be informed of this socio-historical dynamic as they struggle within a cross-cultural context for balance in a reality of extremes: 
If we have the determination to adapt our behaviours and attitudes with the desire to overcome ethnocentrism, we may begin to know the feelings of exhilaration that come when we have made contact with those from other cultures far removed from our own sphere of experience. This willingness to reach out, risk, learn and experience others is a challenge for everyone (France, Rodriquez \& Hett, 2004, p. 55).

As non-Inuk human service professionals such as educators, social workers, and counselors search for balance in Arctic communities it is essential to reflect on the socio-historical context established well before their arrival (France et. al., 2004; Kline, 1992; Kauffman, 2000). A history of colonialist ideologies, oppression and racism (Wayland, 1997) has spawned unequal power relations in favor of southern Canadians over those from the north, and as result, Inuit culture has been under consistent threat from the hegemony of the dominant culture for generations. The complexity of change in northern life that has resulted since contact also includes the following "root causes of social problems": alcohol and drug abuse and addiction, cycles of trauma and abuse, high unemployment rates, family violence, high suicide rates, cultural dissonance and loss of cultural values (Pauktuutit Inuit Women's Association, 2004, p. 18; see also Alexander \& Alexander, 1998; Elrick, 2004; Mankin, 2005; Statistics Canada, 2001a, b).

Across Canada, all children and young people from Aboriginal communities are bearing the fallout from similar socialhistorical-cultural crises. Aboriginal young people are "likely the most vulnerable group of children and youth in Canada today and in the future" (Finlay, ParkerLoewen, \& Mirwaldt, 2005, p. 10). This is most clearly demonstrated through the appalling suicide rate among First Nations and Inuit young people: In Canada, female youth are eight times more likely to commit suicide and males five times more likely than their non-Aboriginal peers (ibid.; see also Blackstock, Clarke, Cullen, D'Hondt, \&
Formsma, J., 2004). In the entire region of the Northwest Territories, the rate of suicide is 43.1 per 100,000 - almost four times the Canadian average of 13 per 100,000 . Some communities have greater rates of suicide than others, and the numbers of adolescents who completed suicide in Nunavut have increased dramatically over the past two decades. For Inuit young people, well-being and health are confounded by multifaceted dimensions of social, psychological, historical and cultural factors including:

+ Cultural stress, loss of spirituality, lack of recreational activities, as well as family breakdown due to death of a relative, alcoholism or abuse. High rates of suicide are also suspected to be exasperated by a somewhat accepting attitude towards suicide among young people.

+ High rates of unsafe sex compounded with early pregnancy and larger families for Inuit women. There is also a high rate of alcohol consumption for pregnant Inuit mothers and resultant higher levels of Fetal Alcohol Spectrum Disorders (FAS/FAE).

+ High rates of substance use, abuse, and addiction including solvent, marijuana, and hashish; although alcohol use has been considered somewhat less of a problem comparatively [It is noteworthy that both cocaine and crystal methamphetamine recently are becoming widely available in Nunavut].

+ Levels of environmental toxins in the North are queried to have a strong relationship with high rates of developmental challenges among Inuit young people.

+ Although the Indigenous language - Inuktitut - is considered strong in Inuit communities, knowledge that is traditionally passed on from Elders using Inuktitut is not reaching young people. This creates further cultural dissonance and intergenerational barriers (see Dickson, 2004; also Stout \& Kipling, 1999).

Arguably, this context of risk is one of Canada's most significant human rights 
challenges at this time. These factors also highlight the complexity of the social and educational arenas that Qallunaat enter when they cross the southernnorthern divide in a professional role.

Moreover, professionals training to work with children across southern Canada are generally unaware of children's human rights, and the implication of Canadian commitments to the United Nations human rights monitoring bodies (UN Convention on the Rights of the Child, 1991; UN Committee on the Rights of the Child, 1995, 2003). This lack of understanding on the part of professionals charged with ethical and democratic practice with young people results from inadequate human rights education across disciplines (Mitchell, 2003a; 2003b; see also Blackstock, Clarke, Cullen, D'Hondt \& Formsma, 2004). As Williams (2005) also notes, the Convention on the Rights of the Child (or CRC) is relatively unknown in Canada, although as a nation Canadians think of themselves as human rights proponents on the world stage. Williams (2005) notes further that the treaty is frequently met with trepidation by Aboriginal peoples many of whom have seen the CRC as yet another instrument of dominant culture oppression. Perhaps wary of previous colonialist ideologies defining the "best interests of the child" (see Kline,1992; Mitchell, 1996), Inuit teens early on requested the treaty be translated into their own Inuktitut syllabics - a rare example of such a translation based upon CRC Article 30 (Onalik,1995).

\section{Overview of the Northern Context}

The new territory of Nunavut is home to fully one-half of the Inuit population, about 26,000 individuals that are scattered among 2 million square kilometers. Nunavut is a new territory since April 1st, 1999 when the region was carved out of the Northwest Territories to change the internal boundaries of Canada for the first time in 50 years and only the second time since confederation (Natural Resources Canada, 2004). Nunavut covers one fifth of Canada's total land mass, (C) Moore, Tulk and Mitchell and is a seemingly boundless wilderness with the kind of severe climate typical of the high Arctic (Alexander \& Alexander, 1998). This cold climate - winter temperatures drop to minus 52 degrees Celsius rising to only 6 degrees Celsius in the summer when the wind chill is taken into account - is composed primarily of barren land and permafrost. This land has been occupied by the Inuit peoples for many thousands of years, and "Nunavut" meaning "Our Land" in Inuktitut, indeed boasts a population of eighty-three percent Inuit. Although many qualities of living are shared among all Inuit peoples of Nunavut-such as the two months of total darkness and near complete darkness for an additional 2 months each year-it is important to note that much variation in lifestyle may be found among communities especially when rural as opposed to urban living is taken into account.

The most recent Canadian census indicates that one million people identify themselves as Aboriginal, and about 5\%, or 45, 000 report they are Inuit. This is a staggering $12 \%$ increase in just past 5 years (Statistics Canada, 2001a). This growth in Inuit population is largely due to demographic factors such as higher fertility rates and increased life expectancy. Although the Inuit birth rate has actually declined in recent years, it is still double the overall non-Aboriginal birth rate while the Inuit population is among the youngest for Aboriginal groups in Canada. The median age for the Inuit population - where one half of the population is older and half is younger - is about 20 years. Of the overall Inuit population about $39 \%$, or 17,500 , are 14 years old or younger (Statistics Canada, 2001b).

Overall these demographics support the notion that the Aboriginal, and Inuit population specifically, is young and growing in Canada (Statistics Canada, 2001a; 2001b). Also, the history of the people of this far northern land has been focused on survival given the extreme climate (Natural Resources Canada, 2004). Nonetheless, the culture of the Inuit people has been dramatically jeopardized since contact 
with peoples from the southern climates (Alexander \& Alexander, 1998; Pauktuutit Inuit Women's Association, 1989; 2004). While they were "pulled" into settlements to obtain better health care, housing and education, they were also "pushed" from the land by decreasing caribou herds and low fur prices that often left the Inuit impoverished. Nobody, it seemed, could foretell the problems that were to come (Pauktuutit Inuit Women's Association, 1989). The Nunavut Land Claims Agreement created in 1993 was both a symbolic gesture and an effort to begin to mend the social fabric torn in this region since contact (Mankin, 2005).

Similar to the colonial ideologies that buttressed assimilation, abuse, discrimination and racism experienced by other Aboriginal people throughout Canada, Inuit families were torn apart through establishment of residential boarding schools and the dislocation of children and young people from their families and communities (Fleras \& Elliott, 2002; Freideres, 1999; 2000; Wayland, 1997). For Inuit children, this led to relocation in larger settlements such as Churchill on the coast of the Hudson's Bay, a center to prepare for a new life in a modernized Arctic (Alexander \& Alexander, 1998). Inuit young people have become trapped between two cultures. Children and young people were removed from their families and their land contributing to a lack of skills for survival such as hunting. The culmination of these processes contributed to a sense of cultural dissonance and loss of cultural values in Inuit communities (Pauktuutit Inuit Women's Association, 2005). Moreover, this pattern of physical and cultural dislocation from traditional teachings that began with residential schools still impacts how current educational systems are perceived. For example, school-based education is still met with apprehension, suspicion and fear by some community members, such that some young people are prevented from entering the new school system by parents and Elders.

Moreover this 'modern Arctic' offers insufficient employment opportunities coupled with a loss of traditional survival skills, and Inuit are often forced to depend on social welfare resulting in a loss of identity and self-esteem. Emerging out of frustration, boredom, and traumatic cycles of abuse many Inuit have also turned to alcohol and drug abuse while others are driven to suicide (Alexander \& Alexander, 1998; Pauktuutit Inuit Women's Association, 2005).

Reflecting upon the fracturing of this collectivist-nomadic society coupled with the youthful population and ancestral capacity for survival in the Arctic region, an opportunity for healing and reconnection presents itself. Young people are found within the educational systems while healers are traditionally the Elders of the Inuit communities (Pauktuutit Inuit Women's Association, 2005). While the majority of the schools focus on an English language curriculum with Qallunaat from regions across Canada, efforts are currently underway to bring Elders into the education system to teach Inuktitut and traditional practices (see Kulchyski, McCaskill \& Newhouse, 1999). From the perspective of Inuit Elder Pauloosie Angmarlik, the important contrast between traditional and contemporary education is described as follows:
We were taught by our ancestors, not in a school system, about hunting, survival skills, and so on. The school children are taken out in good weather only. From my experience the school children should go on outings even if it is not good [weather] so they will learn skills that they need when bad weather hits. They should be taught how to make an igloo if it is really windy out or in a blizzard.... If kids are taught how to survive in bad weather, it would mean building an igloo.... As I have said our ancestors were straight forward (Angmarlik, 1999, pp. 284-285).

Accordingly, although Inuit young people have rights to the preservation of their language and culture within both the educational system and society at large (CRC Article 30; Blackstock, Clarke, Cullen, D'Hondt \& Formsma, 2004), this principle is less of a reality in contemporary practice. 
The majority of educators and professionals come from non-Inuk heritage and Inuktitut is not taught regularly in schools nor is it spoken widely in young people's homes. This barrier to the use of Inuktitut impedes communication with Elders whom most often speak their own indigenous language and are less fluent in English.

In closing this section, the voice of another Inuit Elder, Rachael Uyarasuk from Igloolik, Nunavut, eloquently describes her times, her land and her people:

$$
\begin{aligned}
& \text { Life today is what I find strange. It was } \\
& \text { said that we were changing and I used } \\
& \text { to wonder what this meant and how we } \\
& \text { were changing. We have changed since } \\
& \text { back then. We are no longer scared of } \\
& \text { death. As I grew up I was controlled } \\
& \text { and guided by my older relatives and } \\
& \text { parents. I was not left aside. If we were } \\
& \text { like this now, it would be better. We } \\
& \text { are just disintegrating because we are } \\
& \text { outside. Our young people of today have } \\
& \text { a different life now than when we were } \\
& \text { young (Uyarasuk, } 1999 \text {, p. 272). }
\end{aligned}
$$

This paper now turns to a closer exploration of the lived experience of being Qallunaat educator and the process of confronting some of the challenges discussed above.

\section{Critical Reflection: Voice of a Qallunaat Teacher}

Several questions guide this section in its exploration of finding balance and navigating change: How can Inuit people, skilled counsellors, teachers and other professionals work together to benefit Inuit youth? How can we find a way to balance values with meaning? How can we find that mid-ground between Inuit knowledge, customs, and values - and academic notions that should be balanced with great sensitivity and understanding for the Inuit people? How can we learn from one another? Finally, why is this questioning important at this time? It matters because teachers and other Qallunaat professionals can make a difference, and this author's voice comes from the experience and perspective of one who has taught in the Nunavut region for the last decade. Lived experiences and relationships (C) Moore, Tulk and Mitchell developed in the north are invaluable sources of knowledge that cannot be obtained in a textbook. Furthermore, by integrating practice-based wisdom in this paper, it is hoped that other professionals will be encouraged to practice in a manner that respects and supports young people to return to their communities from the "outside".

It is important for educators to learn how to better counsel all students since much of the teaching day is consumed dealing with students' personal problems. This is unavoidable if learning is to take place, and teaching is no longer confined to mathematical fractions and English poetry. Reflecting back, I know I have grown both professionally and personally while living in the north, but challenging and sometimes tragic events that were centered on my students have forced me to deal with very sensitive issues that tested my strengths and weaknesses. I have come to understand that as an educator one needs to synthesize and implement both teaching and counselling skills. You need to find a way to combine your love of students and their culture, and understand the importance of creating a safe and healthy classroom.

Coming from a cross-cultural context, my professional competencies were shaped by a multitude of factors which included the cultural lens through which I perceived my professional and social worlds in Newfoundland. These included customs, attitudes, values, religious beliefs and practices that shaped my worldview, and what is normal behaviour for the teacher is not necessarily sensible for any of the students. At the same time, educators, counsellors and other professionals need to be conscious of each choice and not excuse unsafe behaviour simply due to cultural factors (France et al., 2004; Goldenberg \& Goldenberg, 2005).

Some teachers feel that simply by teaching the curriculum we are educating and helping Inuit children and young people. I disagree. Personal experiences, supported by research such as France et al. (2004) and others, affirms that educators need to learn, understand and appreciate their own biases and attitudes before they can 
effectively teach and assist youth from other cultures. This responsibility to strive for deeper understanding is the other side of our privileged professional position.

\section{Addressing the Challenges by Striving for Balance}

The following is a synthesis of insights from Inuit Elder healers, discourse related to cross-cultural counselling and practicebased wisdom from restorative justice processes. These are integrated with the aim of providing a framework to guide effective practice when Qallunaat teachers and other professionals work with Inuit young people.

To begin, a definitive definition of 'healer' in Inuit culture doesn't exist as 'healing' is understood as a process; however, we can call on recent research into the characteristics of Inuit healers to inform an approach for professionals in Canada's north. Inuit healers and Elders have been described as follows:

+ warm, enthusiastic, empathetic,

+ humorous, self-confident,

+ focused on the behaviour and not blaming the individual,

+ respectful of those whom they counsel,

+ strong belief in the importance of Inuit culture,

+ practical,

- respect for cultural values, Elders, and Inuit ancestors,

+ awareness of the realities of contemporary Inuit society,

- assertive,

+ able to discuss sensitive topics such as sexual abuse; and

+ hold the belief that people can change (adapted from Pauktuutit Inuit Women's Association, 2004, p. 11).

These qualities of Inuit Elders and healers are similar to the characteristics of effective counsellors and professional helpers from traditionally Eurocentric discourses in counselling psychology (Cormier \& Hackney, 2005; Corsini \& Wedding,
2005; France et al., 2004; Moore, 2004). The links between qualities of indigenous healers and characteristics that facilitate change in western psychotherapy have also entered into discourse in restorative justice as healing justice nationally and internationally (Moore, 2003; 2004; in press), forming a bridge between worldviews.

Restorative justice focuses on the healing of harm by bringing together affected parties in an effort to mend the social fabric of a local community. Since these processes are grounded in wisdom from indigenous cultures the world over, it is not surprising that they also call for facilitators to exude many similar characteristics noted by the Pauktuutit Inuit Women's Association (2004) regarding Inuit healers. In addition, these are focused on the behaviour and not focused on blaming the individual, respectful of those whom they counsel including victims and perpetrators of hurt, involvement and respect for Elders in the community, and a willingness to discuss sensitive topics openly and honestly combined with a respect for the values, beliefs and culture of those involved (Moore, 2004; Van Ness \& Heetderks Strong, 1997; Zehr, 1995).

Other aspects of Inuit healing share similarities with both restorative justice processes, and the healing processes linked with mental health and psychotherapy from Eurocentric discourse (Moore, in press). By integrating these diverse culture-bound perspectives the process of traversing the cross-cultural divide between the northern and southern worlds in Canada may be eased for practitioners. For example, restorative justice shares a focus on with Inuit healing as neither can be categorically defined rather these are major philosophical and social constructions in contemporary society (Moore, 2004, p. 347; see also Blue $\&$ Rogers Blue, 2001; Van Ness \& Heetderks Strong, 1997; Zehr, 1995). The links between the healing potential of restorative justice, and the processes of story-telling and confessional within both Eurocentric psychotherapy and indigenous cultures have now been established (Moore, in press). Similarly: "Inuit healing is about telling one's 


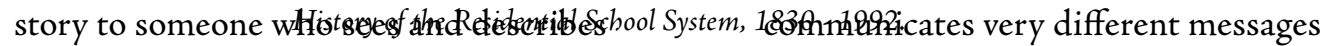

the world in a similar way" (Pauktuutit Inuit Women's Association, 2004, p. 11).

Furthering this exploration, Inuit Elder and healer Meekka Arnakaq shares that Inuit "healing makes you realize what you have forgotten. You feel better, especially when you have been stuck in the same place for a long time" (cited in Dickson, 2004, pp. 10-11). Another Inuit Elder, Angaangaq, explains that Inuit "healing means to help someone stand strong...to help them stand by talking with them, letting their feelings out, letting their thoughts out, so that they may be able to stand....the Inuktitut meaning of healing is that you can speak of your thoughts and your feelings. When you can speak of your feelings, then you can stand strong" (cited in Dickson, 2004, p. 12). It is also essential -across cultures - that individuals in helping relationships also have the capacity to speak of their feelings, have self-understanding, and are assertive and expressive of their thoughts prior to supporting others to do the same (France et. al., 2004; Moore, 2004). Thus, in all of these processes, healing begins with the personal qualities of the Elder, healer, counsellor, professional helper, or educator.

Multicultural competencies in a crosscultural setting include aspects of non-verbal and verbal communication as well as the qualities described above for educators, counsellors and professional helpers. To more effectively work with Inuit young people from a cross-cultural perspective, it is suggested that educators and counsellors consider the following dimensions of communication (adapted from Moore, 2004, p. 352-353):

- Proximity between the educator or professional helper and the student or client. For example, this includes physical distance that is comfortable; degree of face to face contact which varies vastly across cultures: Inuit young people may be uncomfortable with face to face contact.

- Body Movements includes the degree of eye contact, gestures of approval or disapproval such as smiling or frowning. For example, eye contact across cultures, power relations and age: Inuit young people may be reluctant to share direct eye contact with an educator or professional helper.

- Paralanguage includes forms of vocal cues such as hesitations, inflections, silences, intonation, cadence and projection of one's voice: Inuit young people may communicate with fewer words and more silence, choosing non-verbal cues over verbal utterances--- such as raising eyebrows to say 'yes' and wrinkling one's nose to say 'no'. Thus, when carrying on a conversation with Inuit people, words may not be spoken. This is also the case when difficult emotions associated with traumatic events are expressed. Inuit young people are also more likely to "show you" how they feel rather than "tell you". This is highlighted in times of stress, trauma and challenge as emotions may be demonstrated through punching a wall, kicking a chair or fidgeting with hands.

- Density of Language includes the verbal delivery of ideas: Inuit young people may be more receptive to concise, sparse and direct communication from educators or other professionals; although, their response to questions may be circuitous, indirect and more focused on the process of communicating rather than finding answer or relevant response. For example, "the poetry of the story may be more important than the content of the story and may actually be the point of the story" (Umbreit \& Coates cited in Moore, 2004, p. 353). It is important to know that asking questions is not the Inuit way, so questions will not always be answered, or one might not be any wiser even with an answer given. This style of communication contradicts southern Canadian teacher training, for example. This difference in delivery of ideas should not be interpreted as disrespectful or disinterest-much of how the Inuit individuals communicate is demonstrated through observation and telling stories about events.

It is also important to highlight the extreme linguistic difference between Inuktitut 
syllabics and English language. Since 80\% of individuals in Nunavut speak Inuktitut, and in smaller centres this is the primary language, many young people experience more fluency and freedom when using their indigenous language. This is especially true at times of crisis, stress, or trauma. Educators and other professionals may find that students will listen and be attentive to English language speakers, but they may also choose to reply in Inuktitut.

Guidelines for integrating multicultural competencies, cross-cultural counselling, and restorative justice principles into school-based interventions have already been established by Moore (2004). These are combined with the above practicebased insights from a northern teacher and wisdom from Inuit Elders. To achieve a sense of professional and personal balance in northern cross-cultural contexts, Qallunaat may be guided by the following dimensions (adapted from Moore, 2004, pp. 351-352):

\section{Start with Self: self-awareness and} self-knowledge about one's own values, beliefs, worldview and prejudices, as well as emotional and cognitive experiences will build strength and assertiveness in one's approach to enable more effective practice. An integral aspect of this process is the act of bringing one's own culture to the level of consciousness as a central influence upon understanding others and the 'self'. To make assessments and judgments are part of human-ness, but to effectively help others in a crosscultural context, it is often essential to suspend judgment and understand that our personal filters impact interpretations - quite simply things are not always what they seem to be (see also France, et al., 2004; Hernandez, 1997; Miller, 2001).

2. Respect for Diversity \& Individuality: A valuing and respect for another person's worldview, culture and value system, with a genuine curiosity and desire to understand another's perspective, are central to cross-cultural helping relations. It is also important to be open and honest about similarities and differences. This process of opening our selves to understanding diversity can also build personal power while suspending judgment and creating space for diversity aids in selfacceptance (see also France, 2004).

3. Gain Cultural Knowledge \& Encourage Indigenous Language Use: Actively seeking out and accessing knowledge about the heritage and traditions in cross-cultural contexts are important ethical and practical standpoints. This is an ethical responsibility because of our power relationships as professionals working with others in a healing context (France et. al, 2004). For example, it is valuable to know that some Inuit feel that Qallunaat - 'people who pamper their eyebrows' or 'white people' - are nosey, hostile and too free with their opinions. Qallunaat are also credited for their ability to manage and manipulate others. Often these qualities come in conflict with Inuit values, and can make interactions strained or awkward (Pauktuutit Women's Association, 1989). The Inuit culture is passive - almost serene - in which individual goals and successes are of less value when compared to the goals and best interests of the community. In addition, it is also essential to consider language use in the context of valuing culture, heritage and diversity. To value culture sensibly means encouraging indigenous language use and the welcoming of Elders into the school and other systemic contexts-which often increase performance of students, personal capacity of individuals by strengthening cultural identity (see Cummins, 1989).

\section{Building Trust \& Unconditional} Listening: A willingness to listen unconditionally to another's story, history, belief system and spirituality are essential to building trust, and a sense of mutuality. It is also important to be mindful of the severity and frequency of personal and familial violation that are common, but have historical antecedents that have impacted communities through cycles of abuse, 
discrimination and racism. However, many Inuit communities witness Qallunaat professionals leave after brief periods of only 2 years (Pauktuutit Women's Association, 1989), and this process increases apprehension towards building trusting relationships.

5. Being Genuine: Capacities to exude respect, genuineness, availability, congruence are part of the core conditions of helping relationships across contexts (see Rogers, 1957; Raskin \& Rogers, 2005). Cross-culturally, an attitude of humility leaves one open to learning diverse ways of 'being' since the communication of these core conditions becomes increasingly challenging as greater diversity is met. In working within Inuit communities, a "professional front or personal façade" (Raskin \& Rogers, 2005, p.131) will create interpersonal barriers and communication and trust deteriorates.

\section{Being Visible \& A Role Model: A} willingness to open our selves to a wider circle of diversity and experience through engagement in community events allows opportunities for visibility as a role model. This process helps to form diverse connections through which understanding is mutually gained. In this way, opportunities to establish credibility, to seek and solicit support from Elders, and to move beyond being a visitor to becoming an active and accepted member of the community occur. This is especially valuable in small communities since it is essential to understand that relationships extend beyond the boundaries of the school and the classroom, or other professional contexts, into larger social and political systems. For example, in contexts such as teaching Inuit students many of whom have a quiet nature - much learning emerges from participation and attending northern community events. For Qallunaat, opportunities to be with Inuit families and community allow seminal learning to occur regarding traditional ways that are not accessible within textbooks: for example, skidoo hunting trips, traditional childbirth, and survival in the north based upon communitarian values (see also Miller, 2001; Rodriquez, Hett $\&$ France, 2004).

7. Seeking Support \& Guidance: It is essential that individuals know the limits of their capacity to work with others in any context while of heightened concern cross-culturally due to misunderstandings. Support can come from colleagues for one's professional needs, but in contrast, it is important to access the kind of support available only from Elders, respected community members, and individuals that are part of a close social circle. Saliently, this is facilitated only if professionals have already made themselves visible in the community while learning about customs, traditions and the culture of others. In Inuit communities, individuals that are strong, open-minded, bilingual and willing to support Qallunaat are often available. It is also helpful to consider inviting a young person's close friend to participate in the classroom when difficult issues or debriefing of critical incidents are required - as familiar social supports help ease stress (see also France et. al., 2004).

\section{Child Rights-Based Approach:}

Qallunaat must gain knowledge and awareness of how to apply the principles and provisions of the UN's Convention on the Rights of the Child. This human rights-based framework increases capacity for participatory and democratic practices with young people within every cultural context. It is essential that professionals practice an ethical understanding based upon Canada's commitments to the UN to up-hold those rights - particularly those of Inuit and other First Peoples. A rights-based approach respects the dignity, diversity and capacity of children and young people to be partners in social justice and positive structural change.

\section{Final Reflections}

Throughout this paper, the authors have described various aspects of northern life 
for southern professionals who are actively engaged, or anticipating future engagement, within Inuit communities. The aim was to highlight some of the challenges working with this growing and youthful population within a transformative historical epoch. At the same time, an effort was made to provide practical information for Qallunaat or 'people who pamper their eyebrows' as professionals who often struggle to find the personal and professional balance required to survive in this cross-cultural context. To achieve this aim, wisdom from Inuit Elders, practice-based insights from a veteran educator who has crossed the north/south divide, and an analysis of cross-cultural counselling, restorative justice and rights-based techniques argued to be vital for application in the Canadian northern context have been discussed.

\section{Shannon Moore}

Shannon Moore's holds a $\mathrm{Ph} . \mathrm{D}$, in counselling psychology and her research and practice is focused on working with young people, families and communities. Her interests center on the links between mental health and wellbeing, restorative justice, cross-cultural counselling, children's rights and psychotherapy. She is a registered clinical counselor in Canada, lectures graduate and undergraduate students at Brock University, and is involved with community-based restorative justice programs. She has worked as a consultant and private practitioner in mental health and restorative justice in Canada and the United Kingdom.

\section{Wende Tulk}

Wende Tulk is a teacher in Nunavut Territory where she has been working with young people for the past decade, and she is also a recent graduate of the Masters of Education program at Brock University. Her first year of teaching in Canada's northernmost territory was in Cape Dorset, a small Inuit community of 1200 people located on the southwestern tip of Hudson's Bay. Her love of the North and the Inuit People have sustained her in this region, and she feels the experiences and relationships she has developed are invaluable and added to her life immensely both personally and professionally.

\section{Richard Mitchell}

Richard Mitchell is a graduate of the University of Victoria, and a child and youth counselor in British Columbia education, mental health and specialized foster-care for over 20 years. His research and consultancy has focused upon interdisciplinary approaches to supporting the human rights of children and young people. Mr. Mitchell is a $\mathrm{PhD}$ candidate in Sociology and Social Policy with the University of Stirling in Scotland, and his dissertation is entitled "The UN Convention on the Rights of the Child in Postmodernity: A Grounded Systemic Analysis of Children's Rights Educational Policies in Scotland and Canada". He has taught undergraduate and graduate coursework in child and youth care studies, social work and qualitative research methodologies. He is currently on the Organizing Committee for an international child rights conference entitled: "Investment and Citizenship: Towards a Transdisciplinary Dialogue in Child \& Youth Rights" scheduled at Brock University on July 19-21, 2006. (See www.childsrights.ca).

\section{References}

Alexander, B. \& Alexander, C. (1998). The Vanishing Arctic. New York: Checkmark Books.

Angmarlik, P. (1999). Inuit cultures: 'I never say what I have heard, I only tell what I have experienced, because I do not want to lie.' In P. Kulchyski, D. McCaskill, \& D. Newhouse (Eds.), In the Words of the Elders: Aboriginal Cultures in Transition (pp. 273-286). Toronto, ON: University of Toronto Press.

Blackstock, C., Clarke, S., Cullen, J., D'Hondt, J., \& Formsma, J. (2004). Keeping the promise: The convention on the rights of the child and the lived experiences of First Nations children and youth. Ottawa, ON: First Nations Child and Family Caring Society of Canada. Retrieved June 20, 2005, from http://www. fncfcs.com/docs/KeepingThePromise.pdf

Blue, A. \& Rogers Blue, M. A. (2001). The case for Aboriginal justice and healing: The self perceived through a broken Mirror. In M. Hadley (Ed), The Spiritual Roots of Restorative Justice (pp. 57 - 
80). Albany, NY: State University New York.

Corey, G. (2005). Theory and Practice of Counseling E Psychotherapy, $7^{\text {th }}$ ed. Toronto, ON: Thompson Nelson.

Cormier, S. \& Hackney, H. (2005). Counselling Strategies and Interventions, $6^{\text {th }}$ ed. New York: Allyn \& Bacon.

Corsini, R. \& Wedding, D. (2005). Current Psychotherapies, $7^{\text {th }} \mathrm{ed}$. Toronto, $\mathrm{ON}$ : Thompson Nelson.

Cummins, J. (1989). Towards anti-racist education: Empowering minority students. In J. Cummins (Ed.), Empowering Minority Students (pp. 51-65). Sacramento, CA: California Association for Bilingual Education.

Dahlberg, G., Moss, P. \& Pence, A. (1999). Beyond Quality in Early Childbood Education and Care-Postmodern Perspectives. London: Routledge/Falmer.

Dickson, J. (2004). Indigenous women as agents of change. Presentation, United Nations Permanent Forum on Indigenous Issues Standing Committee. (2004, May 12). Retrieved June 20, 2005, from http://64.233.167.104/ search?q=cache:ABA--HTZITAJ:www. pauktuutit.ca/pdf/UNPresentation e.pdf + inuit+children+and +youth+suicide+violenc $\underline{\mathrm{e}+\text { abuse }+ \text { employment }+ \text { statistics } \& \mathrm{hl}=\mathrm{en}}$

Elrick, C. (2004). What Inuit Women Need in Order to Deal with Abuse and Violence. Ottawa, ON: Qullit Nunavut Status of Women Council.

Finlay, J., Parker-Loewen, \& Mirwaldt, J. (2005). Canadian Council of Provincial Child and Youth Advocates: Submission to the Senate Standing Committee on Human Rigbts, February 21, 2005, Ottawa, ON: Canada.

France, H. (2004). Counselling across cultures: Identity, race and communication, In $\mathrm{H}$. France, M. Rodriguez, \& G. Hett, (Eds). Diversity, Culture E Counselling: A Canadian Perspective (pp. 9-28). Calgary, Alt: Detselig.

France, H., Rodriguez, M., \& Hett, G. (2004). Diversity, Culture $\mathcal{E}$ Counselling: A Canadian Perspective. Calgary, Alt: Detselig.

Freire, P. (1971). Pedagogy of the Oppressed. New York: Continuum.

Freire, P. (1985). The Politics of Education: Culture, Power, and Liberation. Handley, Mass: Bergin and Garvey.

Fleras, A. \& Elliot, J. L. (2002). Engaging Diversity: Multiculturalism in Canada, $2^{\text {nd }} e d$. Toronto, ON: Nelson .
Goldenburg, I. \& Goldenburg, H. (2005). Family therapy, In R. Corsini \& D. Wedding (Eds.), Current Psychotherapies, $7^{\text {th }}$ ed. (pp. 372 404). Toronto, ON: Thompson Nelson.

Hernandez, H. (1997). Teaching in Multilingual Classrooms. Columbus, $\mathrm{OH}$ : Prentice Hall.

Holmes, D. \& Gastaldo, D. (2004). Rbizomatic thought in nursing: an alternative path for the development of the discipline. Nursing Pbilosopby, 5, 258-267.

Kaufmann, J. (2000). Reading counter-hegemonic practices through a postmodern lens. International Journal of lifelong Education (19) 5, 430-447.

Kline, M. (1992). Child welfare law, "best interests of the child" ideology, and First Nations. Osgoode Hall Law Journal, 30 (2), 375-425.

Kulchyski, P., McCaskill, D., \& Newhouse, D. (1999). In the Words of the Elders: Aboriginal Cultures in Transition. Toronto, ON: University of Toronto Press.

Kusugak, J. (2004), Round Table on Aboriginal Issues, Speaking Notes. Inuit Tapiriit Kanatami: Publications Corporate. Retrieved June 20, 2005, from http://www.itk.ca/ publications/20040417-en-jose-summit.pdf

Mankin, K. (2005, June 11). Nunavut raises the bar. The Globe and Mail pp. F1-F2.

Matheson, L. (1996, December). Valuing spirituality among Native American populations. Counseling and Values, 41, 51-69.

Miller, H. M. (2001). Becoming a multicultural teacher. The Reading Teacher, 55, 346-357.

Moore, S. A. (2003). Towards and Integral Transformation: Through the Looking Glass of Restorative Justice. Unpublished dissertation: University of Victoria, Canada.

Moore, S. A. (2004). Towards an integrated perspective: Restorative Justice, cross-cultural Counselling and school-based programming, In H. France, M. Rodriguez, \& G. Hett, (Eds.), Diversity, Culture $\mathcal{E}$ Counselling: A Canadian Perspective (332-347). Calgary, Alt: Detselig.

Moore, S. A. (in press). Restorying Restorative Justice $\&$ Transformation: Voices of Participants Inside/Out of Corrections Canada. Jobn Howard Society of Ontario $75^{\text {th }}$ Anniversary Publication. Toronto, ON: Centre for Applied Research and Programme Development.

Mitchell, R. C. (1996). The United Nations Convention on the Rights of the Child and Canadian implementation efforts for indigenous children and youth. Child and Family Social Work, 1 (4), 243-254. 
Mitchell, R. C. (2003a). Ideological reflections on the DSM-IV (or Pay no attention to that man behind the curtain Dorothy!). Child and Youth Care Forum, 32 (5), 281-298.

Mitchell, R. C. (2003b). Canadian health care and child rights-What are the links? Canadian Journal of Public Healtb/Revue Canadienne de Sante Publique, 94(6) , 414-416.

Natural Resources Canada (2004). Nunavut Communities. Retrieved June 20, 2005, from http://atlas.gc.ca/site/english/maps/ peopleandsociety/nunavut/people/communities/1

Onalik, J. (1995). National Inuit Youtb Summit: November 17-20, 1994, Kuujjuaq, Nunavik. Ottawa, ON: Inuit Tapirisat of Canada.

Pauktuutit Inuit Women's Association (1989). A guide to Inuit Culture. Ottawa, ON: Pauktuutit Inuit Women's Association.

Pauktuutit Inuit Women's Association (2004). Analysis Report: Inuit Healing in Contemporary Inuit Society. Ottawa, ON: Pauktuutit Inuit Women's Association. Retrieved June 20, 2005, from http://www.pauktuutit.ca/pdf/publications/ abuse/AHFNuluaqInuitHealing_e.pdf

Pedersen, P. B., Draguns, J. G., Lonner, W. J. \& Trimble, J. E. (1996). Counseling Across Cultures. Thousand Oaks, CA: Sage.

Peart, M. \& King, A. (1996). Health Bebaviours, Attitudes and Knowledge of Young People in the Nortb West Territories, Territorial Report. Ottawa, ON: National Health and Research Development Program, Health Canada.

Rogers, C. (1957). The necessary and sufficient conditions of therapeutic personality change. Journal of Consulting Psychology, 21, 95-103.

Raskin, N. \& Rogers, C. (2005). Person-Centered therapy, In R. Corsini \& D. Wedding (Eds.), Current Psychotherapies, $7^{\text {th }}$ ed. ( pp. 130165). Toronto, ON: Thompson Nelson.

Statistics Canada (2001a). Aboriginal People of Canada: A Demographic Profile. Retrieved June 20, 2005, from http://www12.statcan. ca/english/census01/products/analytic/ companion/abor/contents.cfm

Statistics Canada (2001b). A Portrait of Aboriginal Cbildren Living in Non-reserve Areas: Results from the 2001 Aboriginal Peoples Survey. Retrieved June 20, 2005, from http://www.stacan.ca/english/ freepub/89-597-XIE/2001001/conclusions.htm

Stout, M. \& Kipling, D. (1999). Emerging priorities for the bealth of First Nations and Inuit Children and Youth. Draft Discussion Paper, Prepared for Strategic Policy, Planning and Analysis Directorate,
First Nations and Inuit Health Branch (FNIHB). Ottawa, ON: Health Canada. Retrieved June 20, 2005, from http://www.hc-sc.gc.ca/fnihb/ sppa/ppp/emerging priorities youth.htm

United Nations Convention on the Rights of the Child. (1991). Hull, QU: Canadian Heritage.

United Nations Committee on the Rights of the Child. (1995). Concluding Observations/ Comments: Canada. Retrieved June 16, 2005, from

United Nations Committee on the Rights of the Child. (2003). Concluding Observations/ Comments: Canada. Retrieved June 16, 2005, from http://www.unhchr.ch.

Uyarasuk, R. (1999). Inuit cultures: 'Life today is what I find strange', In P. Kulchyski, D. McCaskill, \& D. Newhouse (Eds.), In The Words of The Elders: Aboriginal Cultures in Transition (pp. 257-272). Toronto, ON: University of Toronto Press.

Van Ness, D. \& Heetderks Strong, K. (1997). Restoring Justice. Cincinnati, $\mathrm{OH}$ : Anderson.

Wayland, S. (1997). Immigration, multiculturalism and national identity in Canada. International Journal of Group Rights, (5), 33-58.

Williams, S. (2005). Meeting Canada's Obligations under the UN Convention on the Rights of the Child: From Paper Concepts to Living Benefits for Cbildren. February 21, 2005 testimony to the Senate of Canada Standing Committee on Human Rights Hearings form International Institute for Children's Rights and Development, University of Victoria, BC. Retrieved June 20, 2005, from http://web.uvic.ca/iicrd/ graphics/IICRDBrieftoSenateCommittee(final).pdf.

Zehr, H. (1995). Changing Lenses: A New Focus on Crime and Justice. Scottsdale, PA: Herald Press. 